\title{
New biologically pure fertilizers in grape nursery
}

\author{
Alexander Verzilin ${ }^{1}$, Yulia Fedulova ${ }^{1}$, and Michael Pimkin ${ }^{1, *}$ \\ ${ }^{1}$ Michurinsk State Agrarian University, 393760, Internatsionalnaya st., 101, Michurinsk, Tambov \\ region, Russia
}

\begin{abstract}
The effect of new biologically pure organic fertilizers, Dia Guma and Gumi Turf, on the yield and quality of grape seedlings on nutrient-poor soils has been studied. The positive effect of silicon organic fertilizer Dia Gum in combination with the growth stimulator Zircon on the survival rate of shanks, the formation of the aboveground part and the root system of plants is shown (the survival rate of shanks in relation to the control (pure water) increases almost 2 times from 36 to $70 \%$, the diameter of growth - from 4.3 to $7 \mathrm{~mm}$, total growth - from 32 to $54 \mathrm{~cm}$, the volume of the root system - from 15 to $25 \mathrm{~cm}^{3}$ ). The use of peat - sapropel concentrate Gumi Peat in combination with the growth stimulator Zircon, according to the results of the yield and quality of the planting material, is close to the use of Dia Guma + Zircon. These fertilizers allow to a greater extent to biologize the process of growing planting material in the nursery.
\end{abstract}

\section{Introduction}

The difficult conditions that have developed recently, in which the Russian Federation finds itself as a result of unfriendly behavior on the part of a number of countries, forced it to give an adequate answer. The logical response from Russia is the import substitution policy [1]. At present, Russia is actively developing and increasing the production of such products for food security. And if it was possible to quickly increase the required volumes for crops such as wheat or soybeans, then for fruit and berry crops, due to their biological characteristics, a certain time is required. Among such industries, at present, in central Russia, an important place is occupied by sheltering viticulture, the development of which is important for the full health of the population.

In recent years, a significant climate change has been taking place in the Central Black Earth region of Russia, in connection with which gardeners have problems with the cultivation of certain grape varieties $[2,3]$. So, a number of scientists-winegrowers note a significant decrease in yield and poor condition of plants in such varieties as Krasa Severa, Tambovskiy Bely, Korinka Russian and others. This led to the fact that amateur gardeners began to abandon the cultivation of this crop.

A significant warming of the climate, as well as the emergence of new varieties, in recent years, as a result of expeditionary surveys of vine plantations and our own

\footnotetext{
${ }^{*}$ Correcting author: luckymiha@mail.ru
} 
observations, have identified new adaptive to local conditions (CBA) large-fruited and large bunch varieties [1] with valuable economic and biological properties [2], resistance of these varieties to biotic and abiotic factors [3-4], to study and recommend the most effective methods of shelter in the cold season $[5,9]$, as well as the conditions for the preservation of shanks in the autumn-winter period $[6,14,15]$.

The research carried out and the efforts of proactive local winegrowers have led to the appearance on the market of new grape varieties, differing in the size of berries, bunches, color, taste, which significantly increased the demand for planting material.

It should be mentiond that in the conditions of risky gardening in central Russia, for the successful cultivation of grapes, the requirements for the quality of planting material must be very high. So, according to A.I. Talash and K.O. Drobot [7], low quality of planting material leads to $50 \%$ loss of bushes on the planted plantation.

One of the main conditions for obtaining high-quality planting material, along with moisture provision, is a sufficient amount of nutrients in the soil. E.A. Egorov et al. On soils with a low supply of nutrients recommends to apply 75-95 $\mathrm{t} /$ ha of organic fertilizers for plantation plowing, $750-950 \mathrm{~kg}$ of ae. potash and $650-850 \mathrm{~kg}$ of i.v. phosphorus fertilizers. Rudenko V.I. along with the main fertilizers, he recommends foliar feeding with manganese, boric acid, zinc sulfate, ammonium sulfate. V.V. Burova, in addition to basic fertilizers, recommends that the first two foliar dressings be carried out using Kemir-Lux, and the Novosil biostimulator should be used at least twice. L.A. Yezhov and P.I. Korsukov [9-13] recommend a $0.005 \%$ sodium humate solution for root and foliar dressing, noting not only an improvement in product quality, but also an increase in soil fertility.

B.U. Miyeriyeva and A.M. Miyeriyev is recommended to use natural growth regulators Epin-extra, Zircon and siliceous fertilizer Siliplant in rural subsidiary farms that are engaged in viticulture $[7,8,12]$. V.V. Chulkov and D.V. Privalov noted a higher growth and development of industrial varieties Kristall and Denisovskiy when using the mineral fertilizer Polyfid at a dose of $3-4 \mathrm{~kg} / \mathrm{ha}[8,10]$. B.A. Seidalieva recommends the environmentally friendly complex fertilizer Tabichinar, obtained as a result of processing man-made waste, which increases the growth and frost resistance of annual shoots, as well as soil fertility [9-12]. Authors E.S. Romanenko and O.I. Sharipova established a positive effect of a $10 \%$ solution of vermicompost extract and $0.15 \%$ lignohumate solution on the growth of the root system and the aboveground part of grape seedlings $[8,9]$.

In recent years, a number of humic and silicon organic fertilizers have been obtained in Russia, which accelerate plant growth and increase soil fertility. Representatives of these fertilizers are Diagum and Gumi Peat (developed by NPK HydroInTech LLC, Sverdlovsk region). Our research in 2017-2019 showed the effectiveness of these fertilizers on fruitbearing grapes plantations. However, data on the effect of these fertilizers on the yield and quality of grape planting material are currently insufficient, and they have not been found in foreign sources.

In this regard, the purpose of our research was to study the effect of peat-sapropel concentrate "GumiTorf" and granular silicon-organic fertilizer "DiaGum" on the growth and development of grape seedlings using the example of the Kristall variety on poor soils in the floodplain of the Lesnoy Voronezh River.

\section{Place and time of research}

The studies were carried out in 2017 - 2018 at the agro-biological station of the Social and Pedagogical Institute of Michurinsk State Agrarian University, which is located in the floodplain of the Lesnoy Voronezh River on an alluvial soddy soil with a low humus content $(2-3 \%)$ and a neutral soil reaction $\left(\mathrm{pH}_{\mathrm{v}}-6,5\right)$. 


\section{Research methodology}

The chemical and physical properties of the soil and its granulometric composition were studied according to generally accepted methods. The application rates of the studied fertilizers were preliminarily agreed with their manufacturers, the total number of shanks in the variant - 50, the number of replicates - 3, in replicates - 15-17 units. The shanks were planted in a previously prepared soil. Soil preparation: plowing of the site; introduction of nitroammophoska $\left(100 \mathrm{~g} / \mathrm{m}^{2}\right)$; introduction of sawdust (mixture of coniferous and deciduous - $6 \mathrm{~kg} / \mathrm{m}^{2}$ ); plowing sawdust and fertilizers (walk-behind tractor); alignment of the site; Spunbond flooring (density $60 \mathrm{~g} / \mathrm{m}^{2}$ ).

Processing of shafts before soaking: shafts in the basal part to a height of $7-8 \mathrm{~cm}$ are pre-treated with a garden saw for furrowing in order to induce callus tissue and improve root formation. Dia Guma $(150 \mathrm{~g} / \mathrm{rm})$ was applied to the soil before cultivation.

Experiment options: 1. Dia Gum (150g/running meter) + Zircon (1ml/10L of water). 2. Humi Peat $(500 \mathrm{ml} / 101$ water). 3. Gumi Peat $(500 \mathrm{ml} / 10 \mathrm{~L}$ of water $)+$ Zircon $(1 \mathrm{ml} / 10 \mathrm{~L}$ of water). 4. Clean water (Control). 5. Zircon ( $1 \mathrm{ml} / 01$ of water).

In option 1 , the shanks were pre-soaked in Zircon solution $(1 \mathrm{ml} / 10 \mathrm{~L}$ of water) for 1 day simultaneously with option 5 and option 3. In option 3, Gumi Peat (500ml/10L of water) was added to the solution simultaneously with Zircon. The option of soaking the shanks in clean water was chosen as a control. The increments of the aerial part were measured with a ruler, the volume of the root system was measured in a measuring cylinder with water. The data obtained were processed by the methods of variation statistics and dispersion analysis.

\section{Observation results}

It should be noted that in 2017 the growing season (April 28) began relatively favorably, but at the beginning of summer in 2017 it was quite cool (evening, night and morning air temperatures in the greater case were in the range of $10-140 \mathrm{C}$, which is not typical for June, In addition, on June 16, on the night of the Agrobiological Station of the Michurinsky State Agrarian University, the air temperature dropped to - 5.60C, and on May 17, a cold drizzling rain fell all day.

Unlike 2017, there were no spring frosts in 2018, the cool spring gave way to rather hot and dry summers and autumn. Weather conditions in 2017 affected the growth and development of seedlings. So, a noticeable regrowth of shoots in 2017 by 23.06 . Was noted only in the Dia Gum variants $(150 \mathrm{~g} / \mathrm{rm})$. + Zircon $(1 \mathrm{ml} / 10 \mathrm{~L}$ of water) and GumiTorf $(500 \mathrm{ml} / 10 \mathrm{~L}$ of water). In other cases, only kidney swelling was noted. Late awakening and the beginning of regrowth can be explained by the lack of heat, because evening, night and morning air temperatures were in the range of 10-140C, which is not typical for June.

Subsequently, the introduction of Dia Guma (150 g/running meter) + Zircon ( $1 \mathrm{ml} / 101$ of water) had a more noticeable effect on rooting and the general condition of grape seedlings (Fig. 1). In this version by the beginning of August took root 35 units of 50 planted shafts. $(70 \%)$, the average growth was $25-30 \mathrm{~cm}$. The survival rate of Crystal shanks in the version of Gumi Peat $(500 \mathrm{ml} / 101)$ of 50 units amounted to 30 units $(60 \%)$, increments $-25-30 \mathrm{~cm}$. In the Gumi version, peat $(500 \mathrm{ml} / 101$ of water $)+$ Zircon $(1 \mathrm{ml} / 101$ of water) of 50 units stuck 34 units $(68 \%)$.

The use of pure Zircon ( $1 \mathrm{ml} / 101$ of water) and soaking of the shanks in clean water reduced the survival rate of the shanks to $45-36 \%$. Further care of the seedlings consisted of regular watering and control over the phytosanitary state of the plants.

The planting of the prepared shanks into the soil in 2018 was carried out 2 weeks earlier than in 2017 (7.05). The absence of frost had a positive effect on the timing and nature of 
shoot growth. So, if in 2017 the regrowth was noted by June 23, then in 2018 it was in almost all variants by June 10-12.

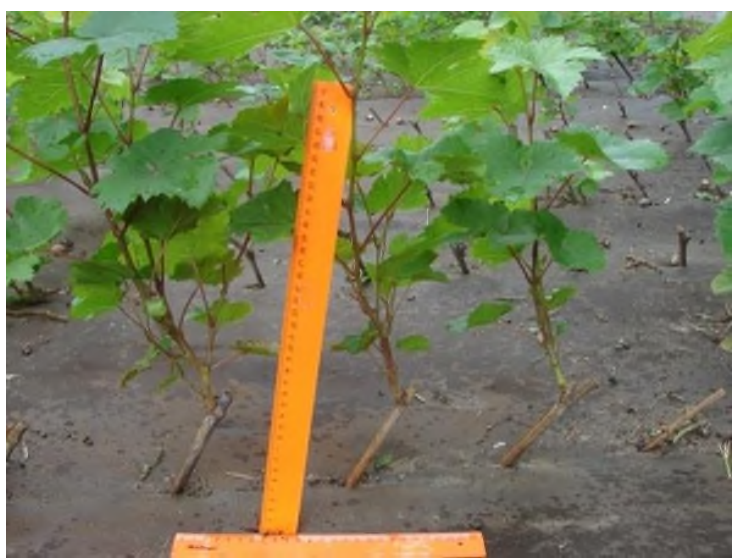

Fig. 1. Increase in the aboveground part of the seedlings in the Dia Gum variant $(150 \mathrm{~g} /$ running meter $)+$ Zircon $(1 \mathrm{ml} / 10 \mathrm{~L}$ of water $)$.

High air temperatures, timely watering, sufficient moisture preservation under the covering material (spunbond, $60 \mathrm{~g} / \mathrm{m}^{2}$ ) ensured good growth and timely ripening of grape seedlings. Analysis of the data obtained showed similar results in the context of options (table 1). So, the best survival rate and other indicators were noted, as in 2017, in the Dia Gum $(150 \mathrm{~g} / \mathrm{rm})+$ Zircon $(1 \mathrm{ml} / 101$ of water) variant.

Table 1. Characteristics of the aboveground part of Kristall grape seedlings, 2017/2018

\begin{tabular}{|l|l|l|l|l|}
\hline \multicolumn{1}{|c|}{ Options } & $\begin{array}{l}\text { The survival } \\
\text { rate of shanks, } \\
\%\end{array}$ & $\begin{array}{l}\text { Trunk } \\
\text { diameter, } \\
\mathrm{mm}\end{array}$ & $\begin{array}{l}\text { The value of } \\
\text { the central } \\
\text { growth, } \mathrm{cm}\end{array}$ & $\begin{array}{l}\text { Total growth } \\
\text { of shoots, } \mathrm{cm}\end{array}$ \\
\hline $\begin{array}{l}\text { Dia Gum }\left(150 \mathrm{~g} / \mathrm{m}^{2}\right)+ \\
\text { Zircon }(1 \mathrm{ml} / 10 \mathrm{~L} \text { of water })\end{array}$ & $70.0 / 83.0$ & $7.0 / 7.1$ & $39.0 / 117.0$ & $54.0 / 183.0$ \\
\hline $\begin{array}{l}\text { Gumi Peat }(500 \mathrm{ml} / 101 \\
\text { water) }\end{array}$ & $60.0 / 65.0$ & $5.9 / 5.8$ & $32.0 / 68.0$ & $47.0 / 94.0$ \\
\hline $\begin{array}{l}\text { Gumi Peat }(500 \mathrm{ml} / 10 \mathrm{~L} \text { of } \\
\text { water) + Zircon }(1 \mathrm{ml} / 10 \mathrm{~L} \\
\text { of water) }\end{array}$ & $68.0 / 76.0$ & $5.0 / 5.7$ & $40.0 / 71.0$ & $50.0 / 102.0$ \\
\hline Zircon $(1 \mathrm{ml} / 10 \mathrm{~L}$ of water) & $45.0 / 55.0$ & $4.7 / 4.8$ & $22.0 / 37.0$ & $40.0 / 63.0$ \\
\hline Water - control & $36.0 / 46.0$ & $4.3 / 4.5$ & $22.0 / 31.0$ & $32.0 / 47.0$ \\
\hline $\mathrm{NSR}_{05}$ & $5.8 / 5.4$ & $0.3 / 0.3$ & $2.4 / 3.7$ & $4.1 / 5.3$ \\
\hline
\end{tabular}

Analysis of the data in Table 1 shows that the best indicators of the aboveground part of the seedlings were noted in the option "Dia Gum 150g / m running." and "Gumi Peat $500 \mathrm{ml} / 101$ of water + Zircon $1 \mathrm{ml} / 101$ of water. The rest of the variants were also superior to the control variant in terms of the studied parameters "survival rate" and "stem diameter".

Table 2. Characteristics of the root system of Kristall grape seedlings, 2017/2018

\begin{tabular}{|l|l|l|}
\hline Options & $\begin{array}{l}\text { Root system volume, } \\
\mathrm{cm}^{3}\end{array}$ & $\begin{array}{l}\text { Height of the root formation } \\
\text { zone, } \mathrm{cm}\end{array}$ \\
\hline $\begin{array}{l}\text { Dia Gum }\left(150 \mathrm{~g} / \mathrm{m}^{2}\right)+\text { Zircon } \\
(1 \mathrm{ml} / 10 \mathrm{~L} \text { of water })\end{array}$ & $25.0 / 37.6$ & $17.6 / 19.2$ \\
\hline Gumi Peat $(500 \mathrm{ml} / 101$ water $)$ & $17.0 / 21.0$ & $14.2 / 14.9$ \\
\hline
\end{tabular}




\begin{tabular}{|l|l|l|}
\hline $\begin{array}{l}\text { Gumi Peat }(500 \mathrm{ml} / 10 \mathrm{~L} \text { of water) }+ \\
\text { Zircon }(1 \mathrm{ml} / 10 \mathrm{~L} \text { of water) }\end{array}$ & $17.0 / 21.7$ & $14.0 / 15.4$ \\
\hline Zircon $(1 \mathrm{ml} / 10 \mathrm{~L}$ of water) & $19.0 / 20.6$ & $14.2 / 14.7$ \\
\hline Water - control & $15.0 / 17.1$ & $14.5 / 14.7$ \\
\hline $\mathrm{NSR}_{05}$ & $2.4 / 2.7$ & $0.4 / 0.6$ \\
\hline
\end{tabular}

Excavation of grape seedlings was carried out on October 25. By the time of excavation, the upper parts of the growths matured well, the apical buds were formed.

According to the indicators "volume of the root system" and "height of the root formation zone" the best option in 2017 and 2018. the option Dia Gum (150g/m linear) + Zircon ( $1 \mathrm{ml} / 101$ of water) was also found. With a root system volume of $25 \mathrm{~cm}^{3}$, the height of the root formation zone was $17.6 \mathrm{~cm}\left(2017\right.$,). In 2018 , these figures were $37.6 \mathrm{~cm}^{3}$ and $19.2 \mathrm{~cm}$, respectively. The rest of the options in terms of the volume of the root system in 2017, except for the option "Zircon (1 ml/10L of water)", were close to the control (Table 2, Figure 2). In 2018, the volume of the root system in all experimental variants was higher in relation to the control.

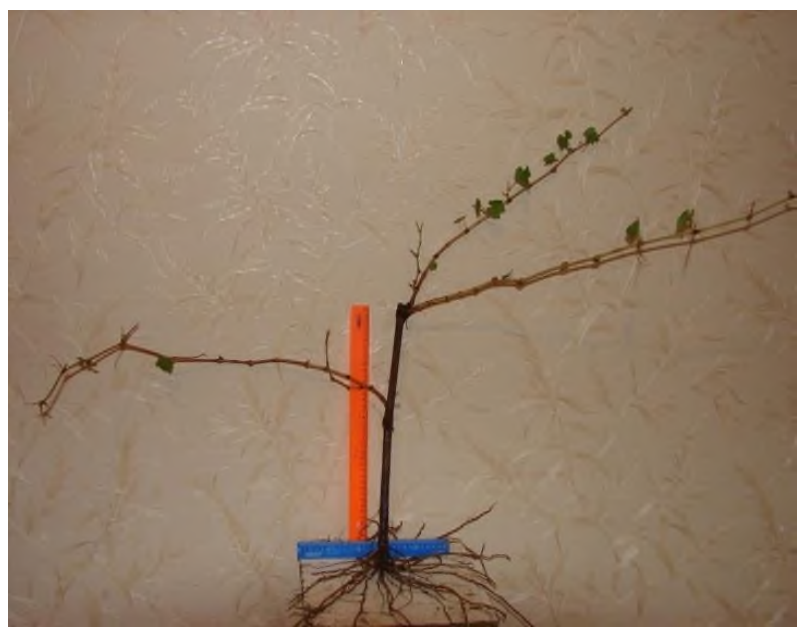

Fig. 2. Development of the root system in the Dia Gum version $(150 \mathrm{~g} /$ running meter $)+$ Zircon $(1 \mathrm{ml} / 10 \mathrm{~L}$ of water).

\section{Conclusion}

Introducing Dia Guma into the soil at the rate of $150 \mathrm{~g}$ per 1 running meter when growing seedlings of Kristall grapes with preliminary soaking of the shanks in a Zircon solution $(1 \mathrm{ml} / 101$ of water) had a positive effect on the survival of the shafts, the formation of the aboveground part and the root system of plants (the survival of the shafts increases almost 2 times from 36 to $70 \%$, the diameter growth - from 4.3 to $7 \mathrm{~mm}$, total growth - from 32 to 54 $\mathrm{cm}$, volume of the root system - from 15 to $25 \mathrm{~cm}^{3}$ ).

The cultivation of grape seedlings by soaking the shanks in a solution of Gumi Peat $(500 \mathrm{ml} / 10 \mathrm{~L}$ of water $)+$ Zircon $(1 \mathrm{ml} / 10 \mathrm{~L}$ of water $)$ is also effective, and according to the studied parameters, the data are close to those of the Dia Gum (150g/running meter) + Zircon ( $1 \mathrm{ml} / 101$ of water)".

Soaking the shanks in a solution of Gumi Peat $(500 \mathrm{ml} / 101$ of water) without Zircon led to a $10 \%$ decrease in survival rate. 
The use of the Zircon preparation ( $1 \mathrm{ml} / 101$ of water) contributed to an increase in the survival rate of shanks by $9 \%$ in relation to the control.

\section{References}

1. A. V. Budagovsky, N. V. Solovykh, M. B. Yankovskaya, M. V. Maslova, O. N. Budagovskaya, I. A. Budagovsky, Effect of spatial coherence of light on the photoregulation processes in cells, Physical Review E., 94(1), 012411 (2016)

2. A. N. Yushkov, N. V. Borzykh, A. I. Butenko, Evaluation of resistance of horticultural plants to destabilizing effects based on analysis of leaf reflection spectra, Journal of Applied Spectroscopy, 83(2), 302-306 (2016)

3. L. V. Grigoreva, Biological growth peculiarities of the cuttings of various rootstocks in a horizontal nursery, International Journal of Pharmaceutical Research, 10(4), 632-640 (2018)

4. A. A. Dubovitski, E. K. Karpunina, E. A. Klimentova, N. V. Cheremisina, Ecological and economic foundations of effective land use in agriculture: The implementation prospects of food security. Proceedings of the 33rd International Business Information Management Association Conference, IBIMA 2019: Education Excellence and Innovation Management through Vision 2020, 2687-2693 (2019)

5. A. I. Kuzin, N. Y. Kashirskaya, A. M. Kochkina, B. I. Smagin, Plant protection and foliar fertilizing technology of apple (Malus domestica Borkh) International Journal of Engineering and Advanced Technology, 8(6), 3613-3620 (2019)

6. O. Yu. Antsiferova, E. A. Myagkova, K. V. Tolstoshein, Formation of the development strategy of the agro-industrial complex of the Tambov region on the basis of the scenario approach, IOP Conference Series: Earth and Environmental Science, 274(1), 012084 (2019)

7. A. V. Verzilin, Grapes as a Valuable Source of Nutrition and Health. Biomedical and Pharmacology Journal, 7, 505-513 (2014) 10.13005/bpj/518. https://www.researchgate.net/publication/276514101_Grapes_as_a_Valuable_Source_ of_Nutrition_and_Health (Last accessed 25.07.2020)

8. A. V. Verzilin, Resistance of grape varieties to biotic environmental factors, Bulletin of $\begin{array}{lllll}\text { Michurinsky State Agrarian University, 4, 6-9 (2017) } & \text { 4, }\end{array}$ https://elibrary.ru/item.asp?id=32205784 (Last accessed 27.07.2020)

9. E. S. Romanenko, Biologically active preparations with growth-stimulating activity in viticulture, Winemaking and viticulture, 3, $44 \quad$ (2011) https://elibrary.ru/item.asp?id=16549657 (Last accessed 27.07.2020)

10. M. Volkova, E. Matveikina, J. Volkov, E. Stranisheshevskaya, Organic viticulture as an important aspect of conserving biodiversity in Crimean agrocenoses, E3S Web of Conferences, 175, $09004 \quad$ (2020) DOI: $10.1051 / \mathrm{e} 3$ sconf $/ 202017509004$ https://www.scopus.com/record/display.uri?eid=2-s2.0

$\underline{85087875036 \& \text { origin }=\text { resultslist\&sort }=\text { plf- }}$

f\&src $=\mathrm{s} \& \mathrm{st} 1=$ Viticulture $\& \mathrm{st} 2=\& \mathrm{sid}=679 \mathrm{~d} 556 \mathrm{bf1}$ da2 $\mathrm{d} 57 \mathrm{a} 47 \mathrm{fb} 34 \mathrm{~b} 0 \mathrm{cf} 760 \mathrm{a} 9 \& \mathrm{sot}=\mathrm{b} \& \mathrm{sd}$ $\mathrm{t}=\mathrm{b} \& \mathrm{sl}=18 \& \mathrm{~s}=$ TITLE $\% 28$ Viticulture $\% 29 \&$ relpos $=4 \&$ citeCnt $=0 \&$ searchTerm $=$ (Last accessed 29.07.2020)

11. V. A. T. Duong, L. Pushkareva, E3S Web of Conferences, 164, 11011 (2020) doi: 10.1051/e3sconf/202016411011

12. C. Venkitasamy, L. Zhao, R. Zhang, Z. Pan, Grapes Integrated Processing Technologies for Food and Agricultural By-Products, 133-163 (2019) 
https://www.sciencedirect.com/book/9780128141380 ISBN: 978-012814139-7; 978012814138-0 doi: 10.1016/B978-0-12-814138-0.00006-X (Last accessed 07.08.2020)

13. A. Nesbitt, S. Dorling, A. Lovett, A suitability model for viticulture in England and Wales: opportunities for investment, sector growth and increased climate resilience, Journal of Land Use Science, 13(4), 414-438 (2018) http://www.tandf.co.uk/journals/titles/1747423x.asp (Last accessed 07.08.2020) doi: 10.1080/1747423X.2018.153731

14. E. Chorti, S. Guidoni, A. Ferrandino, V. Novello, Effect of different cluster sunlight exposure levels on ripening and anthocyanin accumulation in Nebbiolo grapes, American Journal of Enology and Viticulture, 61(1), 23-30 (2010) http://ajevonline.org/cgi/reprint/61/1/23 (Last accessed 08.08.2020)

15. Z. W. Dai, P. Vivin, F. Barrieu, N. Ollat, S. Delrot, Physiological and modelling approaches to understand water and carbon fluxes during grape berry growth and quality development: A review Australian Journal of Grape and Wine Research, 16 (SUPPL. 1), 70-85 (2010) http://onlinelibrary.wiley.com/doi/10.1111/j.17550238.2009.00071.x/pdf doi: 10.1111/j.1755-0238.2009.00071.x (Last accessed 08.08.2020) 